\title{
O Partido Trabalhista Brasileiro no Paraná (1945-1965)
}

\author{
Alessandro Batistella*
}

\section{RESUMO}

O presente artigo visa a analisar a história e a atuação do antigo Partido Trabalhista Brasileiro no Paraná entre os anos de 1945 e 1965, verificando a importância do partido na política paranaense, identificando os membros que integravam a elite partidária, examinando as alas que existiram dentro do partido, as disputas internas pelo poder nas hostes petebistas $\mathrm{e}$ analisando as principais características do PTB no Paraná.

Palavras-chave: PTB; Paraná; trabalhismo; partidos políticos; eleiçôes.

\section{ABSTRACT}

This paper analyzes the history and activities of the former Brazilian Labor Party in the state of Paraná in the period 1945-1965. It verifies the importance of the party in local politics, identifies the members of the party's elite, examines the wings that existed within the party, and how were processed the internal power struggles, and analyzes the main features of PTB in Paraná.

Keywords: PTB; Paraná; Brazilian Labor Party (PTB); political party; elections.

DOI - http://dx.doi.org/10.1590/2237-101X0173213

Artigo recebido em 16 de julho de 2015 e aprovado para publicação em 20 de fevereiro de 2016.

* Universidade de Passo Fundo/RS (UPF), Passo Fundo, RS, Brasil

Doutor em História pela Universidade Federal do Rio Grande do Sul (UFRGS). Professor do curso de História da Universidade de Passo Fundo/RS (UPF). 


\section{A redemocratização de 1945 e a gênese do PTB no Paraná}

Embora o governo Vargas contasse com o apoio de uma expressiva parcela da população brasileira, sobretudo os trabalhadores urbanos, no início de 1945 o fim do Estado Novo e a redemocratização mostravam-se inevitáveis. Sofrendo pressóes internas e externas, o governo Vargas buscou planejar e conduzir o processo de transição, visando à manutenção do poder na nova ordem institucional. Durante esse processo de "transiçáo pelo alto", o governo, a 28 de maio de 1945, decretou a chamada Lei Agamenon, no qual marcou as eleiçóes para o dia 2 de dezembro e regulamentou o novo código eleitoral e os requisitos para a formaçáo dos partidos políticos. A grande inovação da referida lei era a obrigatoriedade, pela primeira vez na história republicana, da formação de partidos de caráter nacional.

Contudo, alguns partidos já estavam se articulando antes mesmo da promulgação da referida lei, dentre estes a União Democrática Nacional (UDN), o Partido Social Democrático (PSD) e o Partido Trabalhista Brasileiro (PTB), que são considerados "criaturas de Vargas", uma vez que gravitavam — de maneiras distintas — em torno da figura do ditador estadonovista.

A UDN surgiu como uma grande frente liberal-democrática de oposição ao Estado Novo e a Getúlio Vargas, que, inicialmente, aglutinava grupos políticos bastante heterogêneos quando não antagônicos - unidos em torno da reconquista das liberdades democráticas, do combate a um inimigo comum — o ditador estadonovista — e do apoio à candidatura do brigadeiro Eduardo Gomes na sucessão presidencial.

No Paraná, em fevereiro de 1945 os grupos opositores a Vargas no estado começaram a articular a Frente Única do Paraná, que reunia, entre outros nomes, o major Plínio Tourinho, Joaquim Pereira de Macedo, Laerte Munhoz, Arthur Ferreira dos Santos, Francisco de Paula Soares Neto, Otávio da Silveira, Bento Munhoz da Rocha Neto, o jornalista Caio Machado e o engenheiro Othon Mader. No final de maio, a Frente Única decidiu ingressar na UDN, dando origem à seção do partido no estado.

Por sua vez, do lado das forças getulistas ocorreu um processo de formação de duas correntes distintas: o PSD e o PTB, "que trariam em suas estruturas e bases organizativas resquícios do Estado Novo" e que "resultaram da frustração do projeto de partido único de massas que vinha sendo acalentado pelo Estado Novo."

O PSD procurou aglutinar as forças políticas tradicionais, reunindo em seus quadros integrantes da máquina administrativa do governo, os interventores estadonovistas, representantes das oligarquias estaduais e alguns segmentos da classe média urbana e da burguesia nacional. Dessa forma, o PSD nasceu com uma sólida infraestrutura administrativa e clientelista nos diversos estados da federação, o que permitiu ao partido lograr êxitos eleitorais. ${ }^{2}$

\footnotetext{
${ }^{1}$ GOMES, Angela Maria de Castro. A invenção do trabalhismo. 3. ed. Rio de Janeiro: FGV, 2005, p. 281-282.

${ }^{2}$ DELGADO, Lucilia de Almeida Neves. Partidos políticos e frentes parlamentares: projetos, desafios e
} 
No Paraná, o PSD foi articulado pelo interventor Manoel Ribas e por integrantes dos altos escalóes da máquina administrativa estadual, como o major Fernando Flores, Roberto Glaser, Angelo Lopes, Lauro Sodré Lopes, e os irmãos Flávio Guimarães, Alô Guimarães e Acyr Guimarães (proprietário do jornal Gazeta do Povo), entre outros.

A definição do formato do PSD praticamente estabeleceu os contornos do outro partido "situacionista": ancorando suas bases na estrutura do Ministério do Trabalho e do sindicalismo estadonovista, utilizando-se das lideranças sindicais e dos organismos previdenciários, o PTB procurou atrair e mobilizar as camadas populares, principalmente nos grandes centros urbanos, para a órbita do partido, apresentando-se como a agremiação partidária que garantiria os direitos sociais e trabalhistas aos trabalhadores. ${ }^{3}$

No Paraná, o PTB teve sua origem diretamente relacionada com o sindicalismo oficial, pois o partido surgiu da União dos Trabalhadores do Paraná (UTP), que era uma espécie de intersindical que aglutinava diversas federaçóes e sindicatos de todo o estado. A UTP foi arquitetada pelo interventor Manoel Ribas e por políticos ligados à interventoria do estado, como o major Fernando Flores e o advogado trabalhista Milton Viana, que articularam com os líderes sindicais estadonovistas a criação da entidade, cujo objetivo era canalizar o sindicalismo ligado ao Estado Novo em uma frente de defesa do legado trabalhista de Vargas. Entre os principais líderes da UTP estavam os sindicalistas Lúcio de Freitas, Maximino Zanon, Joáo Tavares Santana, Alfredo Santana Ribeiro e Bernardino Fialho Sobrinho.

O PTB no Paraná foi oficialmente fundado no domingo do dia 8 de julho de 1945, no qual a UTP — que se transformaria no PTB — preparou uma grande convenção estadual, realizada na Sociedade Duque de Caxias, em Curitiba. Nessa oportunidade ficou definida a primeira Comissão Executiva do PTB no Paraná, presidida pelo sindicalista Maximino Zanon e composta por Lúcio de Freitas (presidente de honra), Vitor Barbosa (secretário), José de Moura (tesoureiro), Bernardino Fialho Sobrinho, José Barbosa de Almeida e Astrogildo Souza (conselho fiscal).

Os primeiros meses de existência do PTB paranaense foram marcados pela inauguração de alguns diretórios pelo interior do estado, aproveitando a estrutura deixada pelos núcleos da UTP nessas cidades. Entretanto, o PTB do Paraná, assim como em todo o país, nasceu como um partido fraco e sem disponibilizar de recursos financeiros.

Em virtude das eleiçóes de dezembro de 1945, o PTB do Paraná lançou, na convenção realizada no final de outubro, dois candidatos ao Senado (Getúlio Vargas ${ }^{4}$ e o líder sindical Theodorico Martins) e oito candidatos à Câmara dos Deputados.

conflitos na democracia. In: FERREIRA, Jorge; DELGADO, Lucilia de Almeida Neves (Orgs.). O Brasil republicano: o tempo da experiência democrática (1945-1964). Rio de Janeiro: Civilização Brasileira, 2003, v. 3, p. 138-139.

${ }^{3}$ GOMES, Angela Maria de Castro. A invenção do trabalhismo, op. cit., p. 283.

${ }^{4}$ A Lei Agamenon, de 28 de maio de 1945, permitia a candidatura múltipla, podendo o candidato concorrer simultaneamente para presidente, senador ou deputado federal num mesmo ou em mais estados. Getúlio Vargas, por exemplo, concorreu a deputado federal em sete estados e a senador em três. 
No que tange à sucessão presidencial, o general Dutra obteve 55\% dos votos contra $35 \%$ do brigadeiro Eduardo Gomes e 10\% do comunista Yedo Fiúza. ${ }^{5}$ No Paraná, apoiado pelo PSD e pelo PTB, Dutra venceu com uma ampla margem de votos $(70,1 \%)$, ao passo que o brigadeiro Eduardo Gomes conquistou 26,1\% dos votos e Yedo Fiúza apenas 3,5\%. ${ }^{6}$

Nas eleiçóes para o Senado, a vitória ficou com os dois candidatos pessedistas, Flávio Guimarães e Roberto Glaser, que obtiveram uma ampla votação, superando, inclusive, as candidaturas de Getúlio Vargas (PTB) e de Luís Carlos Prestes (PCB). Para a Câmara dos Deputados, o PSD também se sagrou amplamente vitorioso, elegendo seis dos nove deputados federais do Paraná, ao passo que a UDN conquistou duas cadeiras e o PTB elegeu somente um deputado: Getúlio Vargas.?

Portanto, as eleiçôes de 1945 no Paraná demonstram algumas tendências já observadas em nível nacional, como a força da máquina partidária do PSD, o grande vitorioso dessas eleiçóes, que contava com uma sólida estrutura administrativa e clientelista no interior do estado. Por sua vez, o PTB paranaense saiu das eleiçóes de 1945 como o terceiro partido.

\section{A relação com Moysés Lupion e as primeiras cisóes no PTB paranaense}

Após as eleiçóes de 1945, o interventor Clotário Portugal — que assumiu após a queda do interventor Manoel Ribas - decidiu exonerar-se do cargo. Para substituí-lo, o presidente Dutra nomeou o advogado pessedista Brasil Pinheiro Machado, que assumiu o governo em 25 de fevereiro de 1946. De acordo com o jornalista Samuel Guimarães da Costa, a missão de Pinheiro Machado era pacificar a política paranaense e garantir uma tranquila sucessão governamental, mas não foi isso o que ocorreu. Primeiramente, porque o novo interventor nomeou um secretariado exclusivamente pessedista, o que gerou grandes descontentamentos entre os demais partidos. Soma-se a isso o fato de o novo interventor fazer campanha eleitoral em favor de si mesmo por meio de festas e comícios no interior do estado. ${ }^{8}$

Por outro lado, ambicionando chegar ao governo do Paraná, o abastado empresário Moysés Lupion utilizou-se da sua fortuna para promover a sua candidatura, inclusive comprando jornais - como O Dia, de Curitiba, e Correio do Paraná, de Londrina, além de 49\% da Gazeta do Povo, de Curitiba - e emissoras de rádios, como a Rádio Sociedade Guairacá Ltda., em Curitiba — que controlava seis outras emissoras no interior do Paraná.

\footnotetext{
${ }^{5}$ FAUSTO, Boris. História concisa do Brasil. 2. ed. São Paulo: EDUSP, 2006, p. 220.

${ }^{6}$ IPARDES. Resultados eleitorais: Paraná (1945-1982). Curitiba: IPARDES, 1989, p. 9.

${ }^{7}$ Getúlio Vargas foi eleito senador da República pelos estados do Rio Grande do Sul e São Paulo (sendo derrotado no Paraná) e eleito deputado federal por sete estados da federação (BA, MG, RJ, DF, SP, RS e PR). Como Vargas optou em assumir a senatoria sul-rio-grandense, quem assumiu a legislatura petebista do Paraná foi o primeiro suplente Rubens de Mello Braga.

${ }^{8}$ COSTA, Samuel Guimarães. História política da Assembléia Legislativa do Paraná. Curitiba: Assembléia Legislativa, 1994, v. 2, p. 363-364.
} 
As pré-candidaturas pessedistas de Pinheiro Machado e Moysés Lupion à sucessão estadual de 1947 acabaram gerando uma crise política no Paraná e polarizando as posiçôes dentro do PSD e do PTB, uma vez que havia dentro desses partidos uma pequena ala simpática ao interventor e outra forte corrente que defendia a candidatura de Lupion.

No PTB do Paraná, Lupion cooptou Maximino Zanon e o seu grupo, que passaram a defender incondicionalmente a sua candidatura ao governo estadual. Inclusive, a candidatura do pessedista Lupion foi oficialmente lançada pelo PTB paranaense, que, ao mesmo tempo, deu início à uma sistemática campanha de oposição ao interventor Pinheiro Machado por meio de um jornal trabalhista denominado Diário Popular, que era financiado por Lupion.

No final de abril de 1946, o PTB paranaense oficializou o rompimento com Pinheiro Machado, o que catalisou uma grave crise interna, pois um grupo de petebistas que não concordavam com o rompimento do partido com o interventor e do apoio dado à candidatura de Lupion foi expulso do partido no final de maio de 1946, configurando a primeira grande cisão dentro do PTB do Paraná.

Em meio à crise, no início de junho de 1946, Maximino Zanon foi reeleito presidente do PTB paranaense durante a convenção estadual, que também elegeu a nova Executiva Estadual, que, após a série de expurgos, sofreu uma significativa mudança, sobretudo pelo fato de muitos dos novos integrantes possuírem algum tipo de vínculo com Lupion, o que contribuiu para o processo de "lupionização" do PTB paranaense.

Tabela 1 - Comissão Executiva do PTB do Paraná (eleita em junho de 1946) ${ }^{9}$

\begin{tabular}{|c|c|}
\hline Presidente de Honra & Lúcio de Freitas \\
\hline Presidente & Maximino Zanon \\
\hline Vice-Presidente & Abilon de Souza Naves \\
\hline Primeiro Secretário & Raul Viana \\
\hline Segundo Secretário & Leonel Prado Martins \\
\hline Terceiro Secretário & João Tavares Santana \\
\hline Primeiro Tesoureiro & Adélio Ramiro de Assis \\
\hline Segundo Tesoureiro & Miguel Raitani \\
\hline Conselho Fiscal & Bernardino Fialho Sobrinho, Rubens de Mello Braga e José Joa- \\
quim Bertolini
\end{tabular}

A referida convenção marcou também a ascensão de Abilon de Souza Naves (então delegado regional do Instituto de Aposentadoria e Pensóes dos Comerciários - IAPC) nas hostes trabalhistas, no posto de vice-presidente, em virtude, sobretudo, dos seus vínculos pessoais com Lupion.

${ }^{9}$ Cf. Diário Popular, 12 jun. 1946, p. 3. 


\section{O PTB e as eleiçóes estaduais de 1947}

Combatido pelo PTB e dentro do seu próprio partido, o PSD, o clima político no Paraná tornou-se insustentável para o interventor Pinheiro Machado, que acabou renunciando e sendo substituído pelo tenente-coronel Mário Gomes da Silva, em outubro de 1946. O novo interventor, que contava com o apoio do PTB, adotou um discurso de pacificar a política paranaense e garantir a idoneidade das eleiçôes estaduais de janeiro de 1947.

Oficializado candidato pela coligação PSD-PTB-UDN-PRP, Lupion enfrentou nas urnas o deputado federal Bento Munhoz da Rocha Neto, do Partido Republicano (PR), que recebeu o apoio dos dissidentes udenistas que não compactuaram com a aliança com o PTB e o PSD. Porém, Lupion, que contava com o apoio oficial dos três principais partidos e dispunha de muitos recursos financeiros, venceu as eleiçóes de 19 de janeiro de 1947 com $59,1 \%$ dos votos, enquanto Bento obteve $29,3 \%$ dos votos. ${ }^{10}$

Para o Senado, o udenista Arthur Ferreira dos Santos (que contava com o apoio do PSD, do PTB e do Partido de Representação Popular — PRP) derrotou o jornalista Roberto Barrozo (Partido Social Progressista - PSP). No que tange à Assembleia Legislativa do estado, o PSD sagrou-se o grande vitorioso, elegendo 16 deputados, enquanto a UDN elegeu sete, o PTB seis, o PR quatro, o PRP dois, o PSP um e o PCB também um. ${ }^{11}$ Dessa forma, Lupion pôde, inicialmente, governar o Paraná com a maioria absoluta do Legislativo, pois a grande coalizão interpartidária aglutinou $83,7 \%$ dos deputados.

\section{O governo Lupion e o "grande cisma” do PTB paranaense}

Empossado em março de 1947, o governador Lupion procurou montar o seu secretariado visando a contemplar os partidos que formaram a grande coalizão que o elegeu. No entanto, o seu governo foi repleto de atritos com a sua base aliada, sobretudo com os udenistas. No final de 1947, a crise entre o PSD e a UDN acentuou-se e o rompimento foi oficializado no início de 1948. A partir de entâo a UDN empreendeu uma ferrenha oposição ao governo Lupion, tornando-se uma implacável e eterna inimiga do governador paranaense.

Internamente, o PSD também entrou em ebulição. De um lado, estavam os deputados lupionistas; de outro, um grupo de deputados rebeldes, que ficaram conhecidos como "granadeiros", ${ }^{12}$ que criticavam abertamente o governador.

\footnotetext{
${ }^{10}$ IPARDES. Resultados eleitorais: Paraná (1945-1982), op. cit., p. 11.

${ }^{11}$ Idem, p. 122.

${ }^{12}$ Os quatro deputados "granadeiros" eram Oscar Lopes Munhoz, Pedro Firman Neto, Alfredo Pinheiro Jr. e Francisco Acioli Filho. O termo "granadeiro" é uma alusão aos arremessadores de granadas explosivas.
} 
Por sua vez, o PTB paranaense também estava em efervescência com a divisão do partido em duas alas (lupionistas e antilupionistas), que disputaram o controle partidário durante a convenção estadual de $1^{\circ}$ de outubro de 1947. O tenso conclave, vencido pelos lupionistas, ficou marcado pela reeleição de Maximino Zanon e por uma significativa renovação na Executiva do partido:

Tabela 2 - Comissão Executiva do PTB do Paraná (eleita em outubro de 1947) ${ }^{13}$

\begin{tabular}{|c|c|}
\hline Presidente & Maximino Zanon \\
\hline Vice-Presidente & Abilon de Souza Naves \\
\hline Secretário Geral & Júlio da Rocha Xavier \\
\hline Primeiro Secretário & Reginaldo Cavalcanti \\
\hline Segundo Secretário & Leonel Prado Martins \\
\hline Tesoureiro Geral & Rene Varumbi de Paula \\
\hline Primeiro Tesoureiro & José Machuca \\
\hline Segundo Tesoureiro & Divonsir Borba Cortes \\
\hline Conselho Fiscal & Raul Viana, José Joaquim Bertolini e Antonio Chalbaud Biscaia \\
\hline
\end{tabular}

Entretanto, a exclusão de alguns influentes trabalhistas do novo Diretório gerou uma crise no PTB paranaense, uma vez que o deputado estadual Aldo Silva, o jornalista Jorge Mathias Jr. e os sindicalistas Bernardino Fialho Sobrinho e Ubiratan Peixoto de Matos, entre outros, ameaçaram abrir uma dissidência nas hostes petebistas, organizando a formação de uma Ala Independente do PTB. ${ }^{14}$

Posteriormente, a situação interna do partido se agravaria no início de 1948, com a morte de Maximino Zanon, em 22 de janeiro. Em seguida, o PTB, dirigido provisoriamente pelo vice-presidente Abilon de Souza Naves, atravessou um período de aguda crise em virtude de uma grande dissidência: em fevereiro, inúmeros trabalhistas, incluindo quatro dos seis deputados estaduais do partido - Antônio dos Santos Filho, Aldo Laval, Aldo Silva, José Daru - migraram para as hostes pessedistas, onde fundaram o Departamento Trabalhista do PSD. ${ }^{15}$

Embora os dissidentes alegassem desentendimentos com a Executiva do partido, há fortes indícios de que o real motivo para a cisão no PTB tenha sido fomentado pelo governador Lupion e pelo PSD ${ }^{16}$ que cooptou os mencionados deputados estaduais e outros influentes petebistas, excluídos das posiçóes de mando do partido, para garantir a maioria no Legislativo e, assim, romper com o PTB e governar o Paraná sozinho, como era a vontade de alguns influentes pessedistas.

\footnotetext{
${ }^{13}$ Cf. Diário da Tarde, 2 out. 1947, p. 6.

${ }^{14}$ Cf. Diário da Tarde, 4 out. 1947, p. 6

${ }^{15}$ Cf. Gazeta do Povo, 22 fev. 1948, p. 1 e 6.

${ }^{16}$ Cf. Diário da Tarde, 13 fev. 1948, p. 1 e 6.
} 
De fato, após estimular a dissidência dentro do PTB, Lupion e o PSD trataram de colocar os petebistas à margem do governo estadual. A partir de então, as relaçóes entre o PTB paranaense e o governador se deterioraram e gradativamente, os petebistas passaram a fazer oposição a Lupion, cujo rompimento foi oficializado, em setembro de 1948.

Após o rompimento com o governador paranaense, o PTB do Paraná passou por um período de grande disputa interna pelos altos escalóes do partido. Na convenção estadual, realizada no dia 16 de outubro de 1949, e que contou com a presença de Salgado Filho entáo presidente nacional do partido - , concorreram dois grupos: de um lado, a chapa de Abilon de Souza Naves (entáo presidente provisório do partido); de outro, a chapa de Francisco Souza Neto (presidente do Diretório Municipal de Ponta Grossa). Com a vitória de Souza Naves, a nova Comissão Executiva sofreu uma grande renovação, com a permanência de apenas três membros da antiga Executiva.

Tabela 3 - Comissão Executiva do PTB do Paraná (eleita em outubro de 1949) ${ }^{17}$

\begin{tabular}{|c|c|}
\hline Presidente & Abilon de Souza Naves \\
\hline Primeiro Vice-Presidente & Parahylio Borba \\
\hline Segundo Vice-Presidente & Rubens de Mello Braga \\
\hline Secretário Geral & Júlio Rocha Xavier \\
\hline Primeiro Secretário & José Machuca \\
\hline Segundo Secretário & Alexandre Zainko \\
\hline Tesoureiro Geral & Emanoel Coelho \\
\hline Primeiro Tesoureiro & José Campelli Filho \\
\hline Segundo Tesoureiro & Elias Defune \\
\hline Conselho Fiscal & Ignácio Iguaçu Franco, Antônio Baby e Dilo de Oliveira Godói \\
\hline
\end{tabular}

No entanto, após a convenção, vários integrantes da chapa derrotada optaram em se desligar do PTB, migrando para o Partido Social Trabalhista (PST). Enfim, a pacificação interna do PTB paranaense ainda estava muito distante de se concretizar.

\section{O PTB e as eleiçóes de 1950}

Nas eleiçôes estaduais de 1950, o PTB do Paraná optou em adotar uma posição de neutralidade, não apoiando oficialmente nenhum candidato à sucessáo estadual, que se encontrava polarizada em torno de dois candidatos: Angelo Lopes (PSD), que representava o continuísmo lupionista; e Bento Munhoz da Rocha Neto (PR), que contava com o apoio oficial da UDN, do PRP, do Partido Libertador (PL) e do PST, formando, assim, uma grande aliança antilupionista.

${ }^{17}$ Cf. Gazeta do Povo, 18 out. 1949, p. 8. 
Nas eleiçóes de 3 de outubro de 1950, Bento obteve 62,9\% dos votos, enquanto Lopes conquistou 30,7\% dos votos e Carlos Amoreti Osório (PSB) apenas 0,1\%. ${ }^{18}$ Além da campanha moralista, a esmagadora vitória de Bento deve-se principalmente à união das forças antilupionistas, que aglutinou diversos partidos, além de uma significativa fração do PTB e de uma ala dissidente do PSD.

Nas eleiçôes para a presidência da República, Getúlio Vargas elegeu-se presidente com $48,7 \%$ dos votos, derrotando o brigadeiro Eduardo Gomes (UDN), que obteve 29,7\% dos sufrágios, e Cristiano Machado (PSD), com 21,5\%. ${ }^{19}$ No Paraná, a vitória de Getúlio Vargas foi esmagadora: 61,6\% dos votos contra 19,9\% do pessedista Cristiano Machado e 14,9\% do udenista Eduardo Gomes. ${ }^{20}$

Nas eleiçôes ao Senado, o PSD paranaense sofreu mais uma derrota: Raul Vaz, amigo íntimo de Lupion, perdeu a eleição para o udenista Othon Mader. Por sua vez, o PTB paranaense optou em abster-se das eleiçôes para a senadoria, não concorrendo com candidato próprio e não apoiando oficialmente nenhum candidato.

No que tange à Câmara dos Deputados, houve um grande equilíbrio: o PSD elegeu três deputados; o PTB também três e a coligação UDN/PR/PST/PRP/PL igualmente três. Na Assembleia Legislativa, por sua vez, embora o PSD tenha conquistado 16 cadeiras, o grande vencedor foi o PTB, que elegeu 12 deputados (o dobro da eleiçáo anterior). Quanto aos demais partidos, a UDN conquistou oito cadeiras, o PR seis, o PSP duas e o PRP uma cadeira. Dessa forma, para garantir a maioria na Assembleia Legislativa, Bento teria que garantir o apoio do PTB.

\section{As disputas pelo poder e a intervenção no PTB paranaense}

No início de 1951, o recém-empossado governador Bento Munhoz da Rocha Neto deu início às conversaçóes com o PTB paranaense, que passou a exigir inúmeras secretarias e nomeaçóes. Como as pastas e os cargos oferecidos pelo governo estadual não eram os desejados pelos petebistas, as negociaçóes entre Bento e o PTB tornaram-se longas e difíceis.

O deputado federal Parahylio Borba (primeiro vice-presidente do PTB paranaense), Estevam Ribeiro de Souza Neto e Wallace Tadeu de Mello e Silva (ambos do diretório de Curitiba) possuíam estreitos vínculos com Bento e defendiam a imediata aliança do partido com o governador. Como a "orientação pragmática" empreendida por Souza Naves estava dificultando a coalizão, planejaram uma manobra para destituí-lo da presidência do partido.

\footnotetext{
${ }^{18}$ IPARDES. Resultados eleitorais: Paraná (1945-1982), op. cit., p. 11.

${ }^{19}$ FAUSTO, Boris. História concisa do Brasil, op. cit., p. 224.

${ }^{20}$ IPARDES. Resultados eleitorais: Paraná (1945-1982), op. cit., p. 9.
} 
Assim, no início de março de 1951, Parahylio Borba convenceu alguns membros da Executiva Estadual a renunciarem aos seus cargos e solicitarem a intervenção de Danton Coelho, então presidente nacional do partido, no PTB paranaense. ${ }^{21}$ A manobra foi bem-sucedida e o Diretório Nacional interveio na seção paranaense, afastando a Executiva Estadual e nomeando, em 13 de maio de 1951, uma comissão de reestruturação partidária presidida por Estevam Ribeiro de Souza Neto e composta por Parahylio Borba e Wallace Tadeu de Mello e Silva.

Assim, se configurou uma luta interna no PTB paranaense pela direção partidária: de um lado, o grupo de Souza Naves (da qual integravam vários parlamentares federais e estaduais); de outro, o grupo de Estevam de Souza Neto e Parahylio Borba. Contudo, após a queda de Danton Coelho da presidência nacional do PTB, ${ }^{22}$ o grupo de Estevam de Souza Neto e Parahylio Borba ficou enfraquecido e na convenção estadual do partido, realizada nos dias 8 e 9 de setembro de 1951 e que contou com a intermediação de Dinarte Dornelles, então presidente da Executiva Nacional, Souza Naves foi reconduzido à presidência estadual do partido, cuja nova Executiva ficou assim constituída:

Tabela 4 - Comissão Executiva do PTB do Paraná (eleita em setembro de 1951) ${ }^{23}$

\begin{tabular}{|c|c|}
\hline Presidente & Abilon de Souza Naves \\
\hline Primeiro Vice-Presidente & Cel. Sílvio Van Erven Jr. \\
\hline Segundo Vice-Presidente & Gastão Vieira de Alencar \\
\hline Terceiro Vice-Presidente & Júlio Rocha Xavier \\
\hline Secretário Geral & José Hoffmann \\
\hline Primeiro Secretário & Jorge de Lima \\
\hline Segundo Secretário & Antônio Annibelli \\
\hline Terceiro Secretário & Divonsir Borba Cortes \\
\hline Tesoureiro Geral & Raul de Rezende Filho \\
\hline Primeiro Tesoureiro & José Machuca \\
\hline Segundo Tesoureiro & Jacinto Cunha \\
\hline Terceiro Tesoureiro & Antônio Baby \\
\hline Conselho Fiscal & $\begin{array}{c}\text { Rubens de Mello Braga, Sebastião Vieira Lins e } \\
\text { Myltho Anselmo da Silva }\end{array}$ \\
\hline
\end{tabular}

Assim, após quatro meses afastados dos postos de comando do PTB paranaense, Souza Naves e alguns membros da antiga cúpula partidária retornaram ao comando do partido, que se encontrava ainda longe de um consenso acerca da posiçáo que tomaria durante o governo de Bento.

\footnotetext{
${ }^{21}$ Cf. Gazeta do Povo, 8 mar. 1951, p. 1.

${ }^{22}$ Enfrentando uma forte oposição nas hostes petebistas, sobretudo a liderada por Ivete Vargas no PTB paulista, Danton renunciou à presidência do partido em junho de 1951. Cf. DELGADO, Lucília de Almeida Neves. PTB: do getulismo ao reformismo (1945-1964). Sáo Paulo: Marco Zero, 1989, p. 111-112.

${ }^{23}$ Cf. Gazeta do Povo, 11 set. 1951, p. 8.
} 


\section{A relação entre o PTB e o governo Bento e a consolidação da liderança de Souza Naves}

Durante o seu governo, Bento, enfrentando a oposição sistemática do PSD, partido majoritário na Assembleia e que dominava a grande imprensa paranaense, passou a cortejar sistematicamente o PTB, inclusive, nomeando Souza Naves para a recém-inaugurada Secretaria do Trabalho e Assistência Social.

No entanto, a relação entre o PTB paranaense e o governador Bento foi repleta de nuanças, com períodos de relativa cumplicidade e outros de discordâncias e desentendimentos. $\mathrm{Na}$ verdade, adotando uma posição equidistante e pragmática, o PTB paranaense revelou-se um partido sem uma posição oficial bem definida e, assim, dividiu-se em duas alas: a "bentista", que barganhava apoio político em troca de cargos e nomeaçóes; e a "independente", capitaneada pelos deputados estaduais Divonsir Borba Cortes e Júlio Rocha Xavier, que defendia a neutralidade do PTB.

Em 1952, ascendeu dentro do PTB do Paraná um grupo de “independentes" progressistas que se manifestavam por meio de um jornal semanal denominado Vanguarda Trabalhista, dirigida pelo jornalista Gamaliel Bueno Galvão que juntamente com os jovens estudantes Manoel Claudius Gomes Pereira e Léo de Almeida Neves (respectivamente presidente e vice-presidente da Mocidade Trabalhista do Paraná, uma ala jovem do PTB paranaense) representavam o grupo dos "pragmáticos reformistas", neste momento ainda uma tendência minoritária dentro do PTB do Paraná, dominado pelos "pragmáticos getulistas". ${ }^{24}$

De acordo com Lucília de Almeida Neves Delgado, ${ }^{25}$ os "pragmáticos reformistas", que ganharam destaque dentro do partido a partir da segunda metade dos anos 1950, defendiam um programa nacionalista e reformista e sua prática político-partidária era um amálgama da tendência "pragmático getulista" e da tendência "doutrinário trabalhista". ${ }^{26}$ Seu principal expoente foi João Goulart, que ascendeu à presidência nacional do PTB na VI Convençáo

\footnotetext{
${ }^{24}$ A ala "pragmático getulistas" era formada pelos profissionais liberais, burocratas vinculados ao Ministério do Trabalho e órgãos previdenciários, empresários e por políticos profissionais. Em geral, era um grande e heterogêneo grupo cuja principal estratégia política era cultivar o carisma e o legado trabalhista de Getúlio Vargas como instrumentos de mobilização política e social. Também integravam este grupo políticos fisiológicos que disputavam cargos e benefícios. Cf. DELGADO, Lucilia de Almeida Neves. Trabalhismo, nacionalismo e desenvolvimentismo: um projeto para o Brasil (1945-1964). In: FERREIRA, Jorge (Org.). O populismo e sua história: debate e crítica. Rio de Janeiro: Civilização Brasileira, 2001, p. 177-178.

${ }^{25}$ DELGADO, Lucilia de Almeida Neves. Trabalhismo, nacionalismo e desenvolvimentismo: um projeto para o Brasil (1945-1964), op. cit., 2001, p. 177-178.

${ }^{26}$ A ala "doutrinário-trabalhista" era "composta pelos intelectuais orgânicos do PTB, cuja proposta centrava-se na idéia de que o partido deveria se organizar sobre uma doutrina trabalhista socializante, propondo um trabalhismo mais autônomo em relação a Vargas e uma maior desvinculação junto ao Estado. Sua influência no partido começou em torno de 1948, com Alberto Pasqualini, e se estendeu até a década de 1960, com Fernando Ferrari, Sérgio Magalhães e San Tiago Dantas". Cf. DELGADO, Lucilia de Almeida Neves. Trabalhismo, nacionalismo e desenvolvimentismo: um projeto para o Brasil (1945-1964), op. cit., 2001, p. 177-178.
} 
Nacional do partido, realizada em 20 de maio de 1952. A ascensão de Jango — o "ungido de Vargas" - significou um marco na história do PTB, pois o novo presidente empreenderia uma nova linha de ação, nacionalista e reformista, que se consolidaria ao longo da história do partido.

No mesmo conclave que elevou João Goulart à presidência do PTB, Abilon de Souza Naves também passou a integrar a Executiva Nacional do partido como quarto vice-presidente. A partir de entáo, Souza Naves aproximou-se de Jango, de quem se tornou um fiel aliado, tornando-se, a partir da convenção nacional de julho de 1953, o segundo vice-presidente nacional do PTB. Portanto, os vínculos que possuía com Getúlio Vargas e João Goulart foram fundamentais para que Souza Naves ascendesse à Executiva Nacional e consolidasse a sua liderança no PTB paranaense, sobretudo após a convenção estadual do partido, realizada em 13 de setembro de 1953.

Tabela 5 - Comissão Executiva do PTB do Paraná (eleita em setembro de 1953) ${ }^{27}$

\begin{tabular}{|c|c|}
\hline Presidente de Honra & Getúlio Vargas \\
\hline Vice-Presidente de Honra & João Goulart \\
\hline Presidente & Abilon de Souza Naves \\
\hline Primeiro Vice-Presidente & José Machuca \\
\hline Segundo Vice-Presidente & Gastão Vieira de Alencar \\
\hline Terceiro Vice-Presidente & Jacinto Cunha \\
\hline Quarto Vice-Presidente & Alexandre Zainko \\
\hline Secretário Geral & Raul de Rezende Filho \\
\hline Primeiro Secretário & Antônio Annibelli \\
\hline Segundo Secretário & Divonsir Borba Cortes \\
\hline Terceiro Secretário & Domício Scaramella \\
\hline Tesoureiro Geral & José Campelli Filho \\
\hline Primeiro Tesoureiro & Anizio Eunápio da Conceição \\
\hline Segundo Tesoureiro & Francisco Silveira Rocha \\
\hline Terceiro Tesoureiro & Parahylio Borba, Estevam Ribeiro de \\
\hline Conselho Fiscal & Souza Neto e Antônio Baby \\
\hline
\end{tabular}

Contando com o apoio dos diretórios de quase todas as regiôes do Paraná, Souza Naves derrotou mais uma vez o deputado federal Parahylio Borba, seu principal adversário dentro do PTB paranaense.

Posteriormente, em virtude do crescimento dos descontentamentos com a posição periférica ocupado pelo partido no governo estadual, alguns setores do PTB, sobretudo a "ala independente", passaram a defender o rompimento com o governador Bento, oficializado no início de abril de 1954.

${ }^{27}$ Cf. Diário da Tarde, 17 set. 1953, p. 6 e 4. 


\section{O PTB e as eleições de 1954 e 1955}

Nas eleiçóes de 3 de outubro de 1954, o suicídio de Getúlio Vargas — ocorrido cerca de 40 dias antes do pleito - náo se tornou um fator decisivo de desequilíbrio a favor dos trabalhistas no Paraná. Na disputa ao Senado, o petebista Parahylio Borba foi derrotado pelo ex-governador Moysés Lupion e por Alô Guimarães, ambos do PSD. No que tange à Câmara dos Deputados, houve um equilíbrio entre os três principais partidos: o PSD elegeu quatro deputados, PTB também quatro, a UDN três, o PR dois e o PSP um. Por sua vez, no legislativo estadual houve um grande equilíbrio entre o PTB e o PSD, com cada um dos partidos elegendo 11 deputados estaduais, enquanto a UDN elegeu oito, o PR e o PSP elegeram sete cada um e o emergente Partido Democrata Cristáo (PDC) elegeu um deputado — totalizando 45 deputados estaduais.

Após as eleiçôes de 3 de outubro de 1954, as atençôes político-partidárias direcionaram-se para as sucessóes presidencial e estadual. No Paraná, especulava-se que o governador Bento renunciaria ao governo paranaense, uma vez que pretendia lançar-se como candidato à presidência da República em 1955. Entretanto, Bento renunciou em 3 de abril de 1955 não para concorrer às eleiçôes de 1955, mas para assumir o Ministério da Agricultura no governo de João Café Filho, de quem era amigo íntimo, permanecendo no cargo até novembro de 1955. Após a renúncia, o governo do Paraná esteve interinamente, durante o mês de abril, nas mãos do deputado petebista Antônio Annibelli, presidente da Assembleia Legislativa, ${ }^{28}$ até que uma eleição indireta elegeu o banqueiro Adolpho de Oliveira Franco como o governador responsável para concluir o mandato de Bento.

No que tange à sucessão estadual, o PTB paranaense oficializou a candidatura do médico e deputado estadual Mário de Barros como o candidato petebista ao governo do Paraná. Nos meses seguintes, os demais partidos foram definindo os seus candidatos à sucessáo estadual: o PSD lançou o nome do senador e ex-governador Moysés Lupion; a UDN oficializou a candidatura do senador Othon Mader; o PSP lançou o deputado federal Luís Carlos Tourinho; por fim, o PSB concorreu com Carlos Amoreti Osório.

No pleito de 3 de outubro, Moysés Lupion sagrou-se vencedor, obtendo 40,8\% dos votos contra 28,9\% de Mário de Barros (PTB), 14,6\% de Othon Mader (UDN), 10,1\% de Luís Carlos Tourinho (PSP) e $0,1 \%$ de Carlos Amoreti Osório (PSB). ${ }^{29}$ Com a desunião das forças oposicionistas, a vitória de Lupion era previsível, uma vez que o ex-governador ainda gozava de grande prestígio junto ao eleitorado paranaense, além de também controlar a grande imprensa do estado e investir muitos recursos financeiros em sua campanha.

No que concerne às eleiçôes presidenciais, a aliança PSD-PTB sagrou-se vitoriosa, com Juscelino Kubitschek sendo eleito presidente da República com 36\% dos votos — derrotan-

\footnotetext{
${ }^{28} \mathrm{Na}$ época não havia o posto de vice-governador, que somente foi criado no início de 1964.

${ }^{29}$ IPARDES. Resultados eleitorais: Paraná (1945-1982), op. cit., p. 11.
} 
do Juarez Távora, da UDN (que obteve 30\% dos votos), Adhemar de Barros, do PSP (com $26 \%$ dos votos), e Plínio Salgado, do PRP (com $8 \%$ dos votos)..$^{30}$ Entretanto, é importante ressaltar que, apesar da força da aliança PSD-PTB, no Paraná JK obteve $24 \%$ dos votos e foi derrotado por Adhemar de Barros, que obteve 28,1\% dos sufrágios, enquanto Plínio Salgado (PRP) obteve $22,8 \%$ e o udenista Juarez Távora obteve $20,1 \%$ dos votos. ${ }^{31}$

Além da grande popularidade que desfrutava o paulista Adhemar de Barros, sobretudo no norte paranaense, outro importante fator que contribuiu para a derrota de JK no Paraná foi a desobediência do PSD e de parte do PTB paranaense (sobretudo os diretórios do norte do estado) em seguir as orientaçóes dos respectivos diretórios nacionais. Particularmente no PSD paranaense, Lupion liberou o diretório do compromisso de votar em JK.

\section{O PTB paranaense e a oposição ao segundo governo Lupion}

Logo no início do seu segundo mandato, Lupion tentou cooptar o PTB oferecendo ao partido a Secretaria de Trabalho e Assistência Social e nomeando para esse cargo o deputado federal petebista Cid Campelo. No entanto, a estratégia adotada pelo governador não surtiu o efeito esperado, uma vez que Souza Naves exigia mais do que apenas cargos periféricos. Assim, sem um acordo oficial, Souza Naves optou em fazer oposição a Lupion, contando com o apoio de importantes lideranças dentro do partido e dos "pragmáticos reformistas", que estavam ganhando espaço nas hostes petebistas.

Por outro lado, havia um grupo dentro do partido que defendia a coalizão com o governador, do qual faziam parte os deputados federais Cid Campelo, Divonsir Borba Cortes e Antônio Baby, além de Parahylio Borba, Rubens de Mello Braga, Sebastião Vieira Lins, Estevam Ribeiro de Souza Neto e diversos prefeitos petebistas do interior do estado, que almejavam receber recursos financeiros do governo estadual para as suas prefeituras.

Portanto, o PTB paranaense encontrava-se, mais uma vez, dividido: oficialmente, encontrava-se em oposição a Lupion, porém, a maior parte da bancada petebista na Assembleia Legislativa não imprimia uma oposição sistemática ao governo, mas sim uma posição colaboracionista em muitos momentos. Tal situação catalisou algumas crises internas dentro do partido durante esse período, pois a ala lupionista pressionava constantemente a Comissão Executiva do PTB, sobretudo o presidente Souza Naves, a aliar-se a Lupion.

Entretanto, a partir de 1957, a ala lupionista do PTB perdeu força dentro do partido, sobretudo porque Lupion esteve envolvido em uma série de escândalos e passou a enfrentar uma forte campanha oposicionista ao seu governo, sobretudo com o agravamento dos

\footnotetext{
${ }^{30}$ FAUSTO, Boris. História concisa do Brasil, op. cit., p. 232.

${ }^{31}$ IPARDES. Resultados eleitorais: Paraná (1945-1982), op. cit., p. 9. 
conflitos agrários na regiáo sudoeste do estado, que mancharam a reputação de Lupion em nível nacional.

\section{A ascensão dos "pragmáticos reformistas" e da ala "plutocrata" no PTB paranaense}

Na segunda metade da década de 1950, durante o governo de Juscelino Kubitschek (1956-1961), o país, apesar de atravessar um período de estabilidade política e de desenvolvimento econômico, presenciou a intensificação dos movimentos sociais urbanos e rurais e a ascensão de setores sociais e políticos progressistas que defendiam, não obstante as diferentes tendências, uma plataforma nacionalista e reformista.

Também foi a partir da segunda metade dos anos 1950 que ganhou espaço dentro do PTB o grupo dos "pragmáticos reformistas", formado por trabalhistas comprometidos com o ideário nacionalista e por um programa de reformas econômicas e sociais. Nesse momento ganham notoriedade novas lideranças petebistas, como Leonel Brizola, Fernando Ferrari, San Tiago Dantas, Roberto da Silveira, Doutel de Andrade, Almino Affonso, entre outros. Inclusive algumas dessas lideranças defendiam uma postura mais agressiva, em termos programáticos, em relação às medidas adotadas por João Goulart. Essa fração aglutinou-se no chamado "Grupo Compacto", defendendo que o PTB deveria adotar um programa mais à esquerda, voltado para a defesa das reformas de base. Articulado em 1958, o Grupo Compacto atuou no interior do PTB, levando-o a adotar posiçóes mais radicais e estimulando-o a aliar-se com outros partidos e políticos de esquerda. ${ }^{32}$

Também defendendo bandeiras comuns, os parlamentares nacionalistas e progressistas dos principais partidos políticos organizaram-se em frentes interpartidárias, dentre elas a Frente Parlamentar Nacionalista (FPN), formada em 1956. Apesar da pluralidade ideológica de seus integrantes e apoiadores, a FPN - que apresentava em seus quadros uma forte predominância do PTB - unia todos em órbita da questão da autonomia nacional. Além de apresentar projetos de leis específicos em relação a questôes nacionalistas, a FPN transformou-se em advogada de defesa das manifestaçóes, greves e reivindicaçóes dos movimentos sociais junto ao Congresso Nacional. ${ }^{33}$

Em 24 de fevereiro de 1957 ocorreu a convenção estadual do PTB do Paraná, na qual seria escolhida a nova Comissão Executiva do partido e que contou com a presença de João Goulart, vice-presidente da República e presidente nacional do partido. Durante a convenção, Jango acompanhou de perto a escolha da nova Comissão Executiva, presidida por

\footnotetext{
32 DELGADO, Lucilia de Almeida Neves. PTB: do getulismo ao reformismo (1945-1964), op. cit., 1989, p. 205-206.

33 DELGADO, Lucilia de Almeida Neves. Partidos políticos e frentes parlamentares: projetos, desafios e conflitos na democracia, op. cit., 2003, p. 149-150.
} 
Abilon de Souza Naves e que passou por uma significativa renovação com o afastamento dos lupionistas - como o deputado federal Divonsir Borba Cortes, do ex-secretário geral Alexandre Zainko e dos ex-membros do conselho fiscal Estevam Ribeiro de Souza Neto e Parahylio Borba. Aliás, a convenção significou a derrota definitiva de Parahylio Borba, que completamente enfraquecido dentro do PTB, migraria para o PSP.

Tabela 6 - Comissão Executiva do PTB do Paraná (eleita em 24 de fevereiro de 1957) ${ }^{34}$

\begin{tabular}{|c|c|}
\hline Presidente & Abilon de Souza Naves \\
\hline Primeiro Vice-Presidente & Antônio Annibelli \\
\hline Segundo Vice-Presidente & Mário de Barros \\
\hline Terceiro Vice-Presidente & Jacinto Cunha \\
\hline Quarto Vice-Presidente & general Iberê de Mattos \\
\hline Secretário Geral & Léo de Almeida Neves \\
\hline Primeiro Secretário & Raul de Rezende Filho \\
\hline Segundo Secretário & Pedro Mariucci \\
\hline Terceiro Secretário & José Teixeira da Silveira \\
\hline Tesoureiro Geral & José Campelli Filho \\
\hline Primeiro Tesoureiro & Libâneo Cardoso \\
\hline Segundo Tesoureiro & Walter Guimaráes da Costa \\
\hline Terceiro Tesoureiro & João Wagner \\
\hline Conselho Fiscal & Antônio Baby, João Cernicchiaro, Herculano Rubim de \\
& Toledo \\
\hline
\end{tabular}

Dentre os novos integrantes da Executiva do PTB paranaense destacava-se um grupo de trabalhistas defensores de um programa nacionalista e reformista, formado pelos deputados estaduais Mário de Barros (candidato do PTB ao governo do Paraná em 1955) e José Teixeira da Silveira, ${ }^{35}$ pelo general Iberê de Mattos ${ }^{36}$ e pelo jovem advogado e jornalista Léo de Almeida Neves, ${ }^{37}$ membro da Mocidade Trabalhista do Paraná e que, aos 25 anos de idade, foi elencado ao posto de secretário geral. Portanto, a convençâo estadual de fevereiro de 1957 representou o início de uma importante mudança interna no PTB do Paraná com a ascensão

\footnotetext{
${ }^{34}$ Cf. O Estado do Paraná, 26 fev. 1957, p. 16.

${ }^{35}$ José Teixeira da Silveira era médico e irmão de Roberto Teixeira da Silveira (do PTB-RJ e governador do estado do Rio de Janeiro entre 1959-1961). Em 1958, foi eleito deputado federal, sendo o único parlamentar paranaense a integrar a Frente Parlamentar Nacionalista entre 1958 e 1962.

${ }^{36} \mathrm{O}$ general Iberê de Mattos era engenheiro civil e ex-diretor da Rede de Viação Paraná-Santa Catarina (RVPSC), onde gozava de grande prestígio entre os ferroviários - o que lhe rendeu o apelido de "general do povo". Ingressou no PTB a convite de Souza Naves. Posteriormente, se elegeria prefeito de Curitiba nas eleiçóes de 1958.

${ }^{37}$ Léo de Almeida Neves destacava-se por seus artigos e ideias próximas à doutrina pasqualinista, o que lhe rendeu o apelido de "Pasqualini paranaense", tornando-se o principal expoente do grupo dos "pragmáticos reformistas" do PTB do Paraná.
} 
de uma ala mais progressista, adepta a um programa nacionalista e reformista, na Executiva estadual — até então amplamente dominada pelos "pragmáticos getulistas".

Por outro lado, Souza Naves, durante o segundo semestre de 1957, intensificou a sua campanha ao Senado e se aproximou dos cafeicultores do norte do estado, procurando trazê-los para a órbita do PTB, dentre eles Nelson Maculan - entáo vereador udenista em Londrina e presidente da Associação Rural da mesma cidade. Além dos cafeicultores, Souza Naves também atraiu para o PTB paranaense alguns abastados empresários, como Miguel Buffara, Petrônio Fernal e Luiz Alberto Dalcanale. Dessa maneira, ascendia no PTB paranaense a "ala dos plutocratas". De acordo com o jornalista e militante comunista Milton Ivan Heller, ${ }^{38}$ seus membros "andavam com camisa de seda e possuíam pouca afinidade com o trabalhismo". Sem dúvida, a aproximaçâo de Souza Naves com empresários e cafeicultores tinha o objetivo de garantir ao partido um grande aporte financeiro para a campanha eleitoral de 1958.

Portanto, com a ascensão dos "pragmáticos reformistas" e dos "plutocratas", configurou-se, a partir de 1957, a formaçáo de três principais tendências dentro do PTB paranaense:

a) A "ala plutocrata" do PTB: formada por empresários e cafeicultores que ingressaram no partido por intermédio de Souza Naves. Em geral, era um grupo conservador e fisiológico com pouca afinidade com o trabalhismo, cuja base política encontrava-se na regiáo norte do estado.

b) O "PTB do centro": liderado por Souza Naves, era o grupo mais numeroso do partido, reunindo políticos e profissionais liberais da corrente "pragmático getulista".

c) O "PTB progressista" ou "pragmático-reformista": composta pelos adeptos dos ideais nacionalistas e reformistas, cujo principal expoente era Léo de Almeida Neves.

d) Souza Naves liderava e aglutinava, com eficiência, as três correntes que existiam dentro do PTB paranaense, uma vez que era um político paciente, conciliador e muito pragmático.

\section{O ingresso de Jânio Quadros no PTB do Paraná e as eleições de 1958}

Abilon de Souza Naves, durante o ano de 1957, adotou uma série de estratégias cujo objetivo era fortalecer o PTB e a sua candidatura ao Senado: esvaziou a ala lupionista e descartou qualquer possibilidade de entendimento com Lupion; atraiu para o partido alguns empresários e cafeicultores que disponibilizariam um importante aporte financeiro para a campanha eleitoral; convidou os deputados dissidentes do Partido Republicano - Amaury de Oliveira e Silva, Silvino Lopes de Oliveira e Chafic Cury — a ingressarem no PTB; e, por

\footnotetext{
${ }^{38}$ Ver o depoimento de Milton Heller em: CODATO, Adriano; KIELLER, Marcio (Orgs.). Velhos vermelhos: história e memória dos dirigentes comunistas no Paraná. Curitiba: UFPR, 2008, p. 103.
} 
fim, deu uma grande cartada: aproximou-se de Jânio Quadros e propôs que o governador de São Paulo concorresse a deputado federal pelo PTB do Paraná.

Sem dúvida, o convite de Souza Naves a Jânio Quadros tinha um claro objetivo eleitoral: encorpar o PTB paranaense com um político popular e conhecido nacionalmente, que pudesse atrair mais eleitores para o partido. E como Jânio estava impedido de disputar algum cargo eletivo em São Paulo, a proposta de concorrer como deputado federal pelo Paraná lhe agradou, pois assim ele teria a possibilidade de ocupar uma cadeira na Câmara dos Deputados até as eleiçóes presidenciais de 1960.

A confirmação da candidatura de Jânio Quadros pelo PTB paranaense ocorreu na convenção estadual de dezembro de 1957, na qual se oficializou a candidatura de Souza Naves para o Senado e a de Nelson Maculan como seu suplente.

No entanto, a presença de candidatos milionários, que gastavam fortunas em suas campanhas eleitorais, provocou grandes descontentamentos em alguns grupos dentro do PTB, que, poucos meses antes do pleito de outubro de 1958, utilizando-se de um conhecido clichê janista, denunciavam a disputa do "milhão contra o tostão" nas hostes trabalhistas. Dessa forma, ocorreu uma polarização e fomentou-se uma rivalidade entre os candidatos petebistas: de um lado, estava a "ala dos ricos"; de outro, a "ala dos pobres", que acusavam os "plutocratas" de utilizar o seu poderio econômico para comprar diretórios e contratar cabos eleitorais - que explicitamente compravam votos - em suas regióes de origem, exercendo, assim, uma concorrência desleal. Em suma, as disputas pelas bases eleitorais regionais entre os petebistas da "ala rica" e da "ala pobre" contribuíram para acirrar os ânimos dentro do partido.

Nas eleiçóes de outubro de 1958 o PTB do Paraná obteve um excelente desempenho, elegendo Souza Naves senador, conquistando a prefeitura de Curitiba com o general Iberê de Mattos e aumentando o número de deputados em nível federal e estadual. Além de eleger o primeiro senador trabalhista, para a Câmara dos Deputados o PTB elegeu seis parlamentares; enquanto o PSD elegeu quatro, a Frente Democrática (UDN-PR-PSP) elegeu dois, o PRP elegeu um (Plínio Salgado, o grande líder do integralismo nacional) e o emergente PDC também um deputado (o major Ney Braga, na época prefeito de Curitiba e o segundo deputado federal mais votado no estado).

No que tange às eleiçóes à Assembleia Legislativa, embora o PTB também tenha apresentado um crescimento, passando de 11 para 13 deputados, o grande vencedor foi o PSD, que aumentou a sua bancada em seis deputados, passando de 11 para 17, enquanto a Frente Democrática (formada por UDN e PR) elegeu sete deputados, o PSP quatro, o PDC três; e a Frente Trabalhista Cristá (coligação entre PRP, PTN e PRT) elegeu um deputado.

Portanto, as eleiçóes de 1958, do ponto de vista eleitoral, foi um grande divisor de águas para o PTB no Paraná, que apresentou um significativo crescimento eleitoral e consolidou-se como uma grande força política no Paraná. 


\section{O PTB do Paraná defende a chapa "Jan-Jan" em 1960}

Após as eleiçóes de 1958, o PTB paranaense manteve a sua posição oposicionista ao governo Lupion e se articulava para a sucessão estadual de 1960, cujo candidato seria o agora senador Souza Naves. Embora os petebistas esbanjassem otimismo e acreditassem que Souza Naves já estava virtualmente eleito governador do Paraná, durante o ano de 1959 também começou a ganhar terreno a candidatura do agora deputado federal e ex-prefeito de Curitiba Ney Braga, do PDC.

Em campanha eleitoral, Souza Naves e Ney Braga iniciaram uma guerra de bastidores, cortejando sistematicamente Jânio Quadros, visando a conquistar o seu apoio no pleito de 1960. Por sua vez, Jânio, que articulava a sua candidatura à presidência da República pelo PDC e havia sido eleito deputado estadual pelo PTB paranaense, optou pela neutralidade.

A partir de uma estratégia política regional, uma vez que a eleição de 1958 havia comprovado que o nome de Jânio Quadros tinha um peso eleitoral significativo no Paraná, Souza Naves e outros petebistas paranaenses passaram a defender a sua candidatura presidencial pelo PTB, passando a articular uma aliança denominada Jan-Jan (Jânio e Jango). Embora Souza Naves tentasse convencer João Goulart, a chapa Jan-Jan era combatida por algumas alas trabalhistas e acabou sendo gradativamente descartada dentro do partido, ao mesmo tempo que cresciam as possibilidades de uma nova aliança com o PSD em torno da chapa marechal Henrique Lott e João Goulart.

Em entrevistas aos jornais, Souza Naves mostrava-se descontente com a provável aliança com o PSD, declarando que "se isso ocorresse se manteria neutro, pois não poderia aliar-se com o PSD paranaense, a quem fazia oposição". ${ }^{39}$ Contudo, a insistência de Souza Naves em defender a candidatura Jan-Jan lhe rendeu alguns problemas dentro da Executiva nacional do partido. Inclusive, a imprensa especulava que Jango iria excluí-lo da nova Executiva, que seria escolhida em outubro de 1959. No entanto, na referida convenção Souza Naves foi reeleito pela terceira vez seguida vice-presidente da Executiva Nacional do PTB, uma vez que gozava da confiança de Jango, de quem era um fiel aliado.

No final de 1959, Souza Naves passou a adotar uma posição dúbia, negando que houvesse compromissos entre o PTB paranaense e Jânio, porém não descartando um futuro compromisso, uma vez que ainda possuía esperanças que a chapa "Jan-Jan" fosse homologada na XII Convenção Nacional do PTB, que seria realizada em fevereiro de 1960. Entretanto, Souza Naves não viveu para defender a sua posição na convenção. Em 12 de dezembro de 1959, durante um jantar realizado em sua homenagem em Curitiba, faleceu, aos 54 anos de idade após sofrer um infarto fulminante. ${ }^{40}$

${ }^{39}$ Cf. Gazeta do Povo, 19 maio 1959, p. 3.

${ }^{40}$ Após a morte de Souza Naves, o suplente Nelson Maculan assumiu a sua cadeira no Senado, enquanto o PTB paranaense passou a ser comandado provisoriamente pelo deputado estadual Antônio Annibelli, primeiro vice-presidente. Já na vice-presidência da Executiva Nacional, João Goulart indicou que o jovem Léo de Almeida Neves (então suplente de deputado estadual) substituísse Souza Naves. 


\section{O PTB e as eleiçóes de 1960}

Com a morte de Souza Naves, o PTB precisava definir quem seria o candidato do partido ao governo do estado. Embora enfrentasse uma forte resistência por parte de algumas alas, o agora senador Nelson Maculan foi paulatinamente ganhando força dentro do partido, contando, inclusive, com o apoio de João Goulart. Desse modo, Nelson Maculan foi oficializado como o candidato petebista à sucessão estadual em fevereiro de 1960.

Desse modo, no início de 1960, os partidos políticos paranaenses estavam definindo as suas posições no que tange à sucessão estadual. Além do petebista Nelson Maculan, Ney Braga (PDC) já estava em campanha desde o segundo semestre de 1959; o PSD que atravessava um momento difícil em virtude das acusaçóes de corrupção a Lupion lançou Plínio Franco Ferreira da Costa; a UDN, por sua vez, também enfrentando um momento difícil em decorrência do mau desempenho nas eleiçóes de 1958, optou em não lançar candidato próprio.

Em âmbito nacional, em fevereiro de 1960 ocorreu a XII Convenção Nacional do PTB, na qual foi homologada a coalizáo com o PSD e o lançamento da chapa Lott-Jango para a presidência da República. ${ }^{41}$ No entanto, a maior parte do PTB paranaense, que desde 1959 mostrava-se propenso a apoiar Jânio Quadros, optou por desobedecer à decisão da Executiva Nacional e passou a fazer campanha, de forma velada, em prol da chapa Jan-Jan. Assim, durante a campanha eleitoral, Nelson Maculan e outros petebistas paranaenses evitaram participar de comícios ao lado do marechal Lott.

Entretanto, tal situação acabou gerando uma crise interna, uma vez que havia um pequeno grupo - capitaneado pelo deputado federal José Teixeira da Silveira e, sobretudo, pelo deputado estadual Waldemar Daros — que constantemente denunciava à imprensa a traição dos petebistas paranaenses ao marechal Lott.

Embora tenha contado com o aporte financeiro dos "plutocratas" do PTB, a campanha política de Nelson Maculan, ancorada principalmente na solução dos problemas dos cafeicultores do norte do estado, era acusada de ser demasiadamente elitista e não emplacou em diversas regióes do Paraná, sobretudo em Curitiba, onde o candidato petebista ainda era um "ilustre desconhecido".

Sem o apoio oficial de Jânio Quadros, Ney Braga — cuja principal plataforma de campanha era resolver o problema do abastecimento de energia elétrica no Paraná - contou com o apoio da maior parte da UDN, de parte do PR, de setores da Igreja católica e de grupos empresariais e ruralistas de diversas regióes do estado. Já Nelson Maculan foi apoiado pelo ex-governador Bento Munhoz da Rocha Neto, pelos udenistas do norte, por parte do

\footnotetext{
${ }^{41}$ D’ARAUJO, Maria Celina. Sindicatos, carisma \& poder: o PTB de 1945-1965. Rio de Janeiro: FGV, 1996, p. 130-131.
} 
PSP, pela dissidência do PSD e pelo Partido Comunista do Paraná, que chegou a publicar um manifesto de apoio ao marechal Lott, a Jango e a Maculan. ${ }^{42}$

Em outubro, Ney Braga elegeu-se governador do Paraná com 35,3\% dos votos, contra $30,9 \%$ de Nelson Maculan e 26,8\% de Plínio Costa. ${ }^{43}$ Com exceção da região oeste/sudoeste (onde o PTB era muito forte) e da cidade de Londrina, base eleitoral de Maculan, Ney Braga venceu nas demais regiôes e nas principais cidades do estado.

No que concerne às eleiçôes presidenciais, Jânio Quadros (PDC) elegeu-se presidente da República, obtendo $48 \%$ dos votos contra $28 \%$ do marechal Henrique Lott (PSD/PTB) e $23 \%$ de Adhemar de Barros (PSP). No Paraná, Jânio venceu com uma grande margem de votos, obtendo $51,2 \%$, enquanto Adhemar obteve $22,6 \%$ e o marechal Lott apenas $16,9 \%{ }^{44}$. Um dos fatores que contribuíram para o fraco desempenho eleitoral do marechal Lott no Paraná deve-se ao fato da maior fração do PTB paranaense ter apoiado Jânio Quadros, que também contou com o apoio do eleitorado neyista e udenista. Soma-se a isso também a popularidade de Adhemar no norte do estado.

Enfim, após as eleiçóes de outubro de 1960, o PTB paranaense enfrentaria novas turbulências causadas não somente pela repercussão da derrota eleitoral, mas, sobretudo, em virtude da aproximaçáo da convençáo estadual de janeiro de 1961, que catalisou uma ferrenha disputa pela presidência do partido entre o senador Nelson Maculan, o deputado federal Miguel Buffara, o prefeito de Curitiba general Iberê de Mattos e o deputado estadual Léo de Almeida Neves (que era um dos vice-presidentes da Executiva Nacional). Ademais, o partido também se mostrava dividido em dois grupos: um majoritário, que defendia a oposição ao governo Ney Braga; e outro, liderado pelo deputado federal Jorge de Lima, que defendia uma coalizão com o novo governador paranaense.

\section{A convenção do PTB paranaense de 1961}

Contando com o apoio dos diretórios do norte do estado, Nelson Maculan, após uma série de conversaçóes com as outras alas do partido, conseguiu aglutinar um considerável apoio político e, em dezembro de 1960, já era apontado pela imprensa como o novo presidente petebista. Todavia, o consenso em nome de Maculan náo pacificou o PTB, pois houve uma acirrada competiçáo pelo posto de vice-presidente do partido.

Alguns dias antes da convençấo estadual, que seria realizada em janeiro de 1961, a disputa pela vice-presidência delimitou-se entre os deputados estaduais Amaury Silva e Antônio

\footnotetext{
${ }^{42}$ Tal fato foi muito explorado pela imprensa paranaense (que "denunciava" os vínculos entre Maculan e os comunistas, apesar de Maculan ter recusado publicamente o apoio de Prestes e dos comunistas) e por setores da Igreja católica, favorecendo, assim, a candidatura de Ney Braga.

${ }^{43}$ IPARDES. Resultados eleitorais: Paraná (1945-1982), op. cit., p. 11.

${ }^{44}$ Idem, p. 9.
} 
Annibelli (então presidente em exercício). Porém, Amaury costurou alianças com diversos grupos petebistas e formou uma forte chapa, da qual faziam parte o general Iberê de Mattos (como segundo vice-presidente) e Léo de Almeida Neves (como secretário geral). ${ }^{45}$ Assim, Nelson Maculan e Amaury Silva foram eleitos, respectivamente, presidente e primeiro vice-presidente do PTB paranaense.

Tabela 7 - Comissão Executiva do PTB do Paraná (eleita em janeiro de 1961) ${ }^{46}$

\begin{tabular}{|c|c|}
\hline Presidentes de Honra & Getúlio Vargas e Abilon de Souza Naves \\
\hline Presidente & Nelson Maculan \\
\hline Primeiro Vice-Presidente & Amaury Silva \\
\hline Segundo Vice-Presidente & general Iberê de Mattos \\
\hline Terceiro Vice-Presidente & Domício Scaramella \\
\hline Quarto Vice-Presidente & Miguel Dinizo \\
\hline Secretário Geral & Léo de Almeida Neves \\
\hline Primeiro Secretário & Wilson Chedid \\
\hline Segundo Secretário & Rubens de Mello Braga \\
\hline Terceiro Secretário & Luiz Alberto Dalcanale \\
\hline Tesoureiro Geral & José Campelli Filho \\
\hline Primeiro Tesoureiro & Miran Pirih \\
\hline Segundo Tesoureiro & Jorge Nassar \\
\hline Terceiro Tesoureiro & Marino Pereira \\
\hline
\end{tabular}

Entretanto, após a derrota na convenção, Antônio Annibelli e o seu grupo - que contava com os deputados federais Jorge de Lima e Kalil Maia Neto, além dos deputados estaduais Libâneo Cardoso, Elias Nacle e Pedro Liberti - mostravam-se inconformados com a derrota e com o consequente alijamento da cúpula partidária, passando a empreender uma ferrenha oposição ao grupo de Maculan e Amaury. ${ }^{47}$

Além da disputa pelos altos escalóes partidários, na convenção petebista também seria decidido se o partido apoiaria ou náo o governo de Ney Braga. Nesse sentido, o partido mostrou-se, mais uma vez, dividido. De um lado, havia o grupo liderado por Antônio Annibelli, que o apoio do partido aos governos de Jânio Quadros e Ney Braga; de outro lado, havia o grupo de Amaury Silva e Léo de Almeida Neves, que defendiam que o partido deveria manter-se em posição de "independência e vigilância perante os governos federal e estadual, conforme a orientação dada por João Goulart". ${ }^{48}$ Como o grupo de Amaury Silva sagrou-se vitorioso na convenção, o PTB paranaense adotou inicialmente uma posição de independência perante o governo Ney Braga.

\footnotetext{
${ }^{45}$ Cf. Diário da Tarde, 13 jan. 1961, p. 1.

${ }^{46}$ Cf. Gazeta do Povo, 17 jan. 1961, p. 5 e 8.

${ }^{47}$ Cf. Diário da Tarde, 17 jan. 1961, p. 1.

${ }^{48}$ Cf. O Dia, 15 jan. 1961, p. 2.
} 
Em suma, a convençâo estadual não foi capaz de unificar o PTB do Paraná, que se mostrava cindido entre os grupos de Amaury e Annibelli. Soma-se a isso o início, a partir de março de 1961, de uma intensa disputa entre os petebistas em torno da definição dos candidatos do partido ao Senado, em 1962.

\section{O PTB paranaense, o governo Ney Braga e as eleiçóes de 1962}

Ao assumir o governo do Paraná no início de 1961, Ney Braga tinha ciência que enfrentaria a oposição do PSD, que tinha 17 deputados na Assembleia Legislativa. Como a sua base aliada - formada por PDC, UDN e PR - era insuficiente para fazer frente aos pessedistas, o governador viu-se obrigado a se aproximar do PTB, oferecendo aos petebistas duas secretarias e a diretoria do Banco do Estado do Paraná (Banestado).

Todavia, ao mesmo tempo que negociava com o PTB, Ney Braga também propôs uma vantajosa aliança eleitoral a Amaury Silva, até então contrário à aproximaçáo com o governo, mas que ambicionava eleger-se senador e era tido como o virtual candidato petebista. Segundo o acordo PDC-PTB-UDN, o PTB e a UDN lançariam, cada um, somente um candidato ao Senado, que teriam o apoio do governador e do PDC. Em troca, o PDC lançaria o candidato à sucessão municipal de Curitiba, que deveria contar com o apoio dos petebistas e dos udenistas.

Desse modo, Ney Braga cooptou Amaury Silva, que trabalhou intensamente nos bastidores do partido para consolidar o acordo do PTB com o governador. Entretanto, o Diretório Municipal de Curitiba e alguns membros da ala "pragmático-reformista" mostravam-se contrários ao acordo com o governador, dentre os quais o jornalista Jorge Mathias Jr., o prefeito de Curitiba general Iberê de Mattos, os deputados estaduais Waldemar Daros e João Cernicchiaro, e Walter Alberto Pecoits (prefeito de Francisco Beltrão), entre outros. ${ }^{49}$

Na convenção estadual do PTB, realizada em fevereiro de 1962, a candidatura de Amaury Silva foi oficializada e decidiu-se pela delegação de poderes à Executiva Estadual para que essa conduzisse as negociaçôes com a UDN e o PDC.50 Posteriormente, Nelson Maculan e Amaury Silva, que comandavam a Executiva Estadual, selaram a aliança com Ney Braga e oficializaram a coalizão PDC-PTB-UDN-PTN (denominada de "quadrilátero situacionista"), lançando a chapa Amaury Silva e Adolpho de Oliveira Franco (UDN) ao Senado.

Todavia, faltava ao PTB cumprir a sua parte no acordo e consumar o apoio do partido a Ivo Arzua, candidato pedecista à prefeitura de Curitiba. No entanto, o Diretório Municipal de Curitiba mostrou-se irredutível e não compactuou com o acordo articulado pela Executiva Estadual, lançando a candidatura do vereador Carlos Alberto Moro à sucessão da capital.

\footnotetext{
${ }^{49}$ Cf. Diário da Tarde, 4 nov. 1961, p. 3.

${ }^{50}$ Cf. Diário da Tarde, 19 fev. 1962, p. 1 e 4. 
Assim, fomentou-se uma nova crise interna no PTB, envolvendo a Executiva estadual e o Diretório Municipal de Curitiba.

Nas eleiçóes de 7 de outubro de 1962, Amaury Silva e o udenista Adolpho Franco foram eleitos para o Senado. Dessa maneira, a aliança PTB-PDC-UDN-PTN para o Senado foi praticamente invencível, derrotando dois "caciques" da política paranaense (os ex-governadores Bento Munhoz da Rocha Neto e Moysés Lupion). Esse fato é bastante emblemático, pois demonstra a consolidação do PTB e do neyismo como as principais forças políticas do Paraná.

Nas eleiçôes à Câmara dos Deputados, o PTB sagrou-se o grande vencedor, conquistando nove cadeiras; a Aliança Movimento Democrático Renovador, formada por UDN-PDC-PTN, elegeu também nove deputados, enquanto o PSD elegeu seis deputados e o PRP elegeu um deputado. No que tange à Assembleia Legislativa, o grande vencedor foi o PDC de Ney Braga, que elegeu 12 deputados estaduais; o PTB elegeu também 12 deputados, enquanto a UDN elegeu oito, o PSD apenas sete; e a Frente Rural Cristã Trabalhista (conhecida como "Frentinha", coalizão formada por PR-PRP-PSP-PTN-PST-MTR) conquistou seis cadeiras. Por fim, Ivo Arzua (PDC) derrotou Carlos Alberto Moro (PTB), elegendo-se o novo prefeito de Curitiba.

Portanto, as eleiçôes de 1962, em nível estadual, comprovam que o governador Ney Braga havia se consolidado como o principal e mais prestigioso líder político do Paraná naquele contexto. Por consequência, o PDC obteve um crescimento meteórico, quadriplicando a sua bancada e passando a rivalizar com o PTB pelo posto de maior partido político do estado.

O pleito de 1962 foi amplamente favorável a Ney Braga, uma vez que o PDC conquistou 12 cadeiras e a UDN oito (totalizando vinte), contra apenas sete do PSD. Embora o PTB também tivesse conquistado 12 cadeiras, o reequilíbrio das forças possibilitaria ao governador não ser mais tão dependente do apoio dos petebistas, desde que garantisse o apoio da "Frentinha", que conquistou seis cadeiras. Dessa forma, os círculos políticos paranaenses já previam que o divórcio entre o PTB e Ney Braga ocorreria tão logo os novos deputados tomassem posse, no início de 1963 , uma vez que a aliança não seria mais tão vantajosa nem para o PTB nem para o situacionismo.

De fato, o iminente rompimento foi oficializado em março de 1963. Contudo, após o divórcio o PTB não chegou a empreender uma oposição sistemática a Ney Braga. Com exceção de Waldemar Daros, Walter Pecoits e Leon Naves Barcelos, que faziam ampla oposição ao governo, os demais deputados petebistas adotaram uma posição independente.

\section{O PTB paranaense, o governo João Goulart e o golpe civil-militar de 1964}

Após a volta do presidencialismo, no primeiro semestre de 1963 o projeto de governo de João Goulart ancorou-se no Plano Trienal, formulado por Celso Furtado, ministro extraor- 
dinário do Planejamento. Porém, praticamente todos os grupos nacionalistas e reformistas, aglutinados na Frente de Mobilização Popular (FMP) sob a liderança de Leonel Brizola, criticavam duramente o plano de Furtado, pressionando o Congresso e Jango por medidas concretas e de curto prazo para a implantação das reformas de base. ${ }^{51}$

Em dificuldades políticas, Jango viu o Plano Trienal sucumbir ainda no primeiro semestre de 1963, o que o levou a realizar uma reforma ministerial em junho. Assim, em substituição ao petebista Almino Affonso, Jango nomeou, em junho, para a pasta do Trabalho o senador (e vice-presidente do PTB do Paraná) Amaury de Oliveira e Silva, integrante da FPN e um "pragmático-reformista" de tendências mais moderadas do que seu antecessor.

Segundo José Pedro Kunhavalik, o relativo apoio de Ney Braga ao governo federal levou Goulart a ceder um ministério para o Paraná - e o escolhido foi um membro do PTB paranaense. Presidente nacional do PDC, Ney Braga também foi consultado sobre a nomeação de um ministro pedecista, cujo escolhido foi o deputado federal pelo PDC paulista Paulo de Tarso, que assumiu o Ministério da Educação e Cultura. ${ }^{52}$

Ainda segundo Kunhavalik, em julho de 1963 Ney Braga também indicou a Goulart a nomeação do seu secretário da Agricultura, Paulo Pimentel, para a presidência do Instituto Brasileiro do Café (IBC). Porém, como Jango não queria fortalecer ainda mais Ney Braga no Paraná, nomeou o senador (e presidente do PTB paranaense) Nelson Maculan para o cargo. Conforme o autor, a nomeação de Maculan e as nomeaçóes nos IAPs (Institutos de Aposentadorias e Pensóes), que favoreceram o PTB em detrimento do PDC, determinaram o afastamento de Ney Braga/PDC de Jango. ${ }^{53}$

Naquele contexto em que o PDC e o PTB disputavam a hegemonia política no estado, Ney Braga disse que "a nomeação de Nelson Maculan para a presidência do IBC obedecia a um esquema político visando à sucessão estadual de 1965", "ressaltando que o presidente da República tem demonstrado interesse no fortalecimento do seu partido com as nomeaçôes dos senadores Maculan para o IBC e Amaury Silva para o ministério do Trabalho". E acrescentou: "havia fortalecido um candidato provável ao governo do Estado; agora está fortalecendo o outro". ${ }^{4}$

Também no segundo semestre de 1963, a crise econômica e política acentuava-se em nível nacional. No Paraná, Ney Braga já se mostrava cada vez mais distante de Jango. Na convenção estadual do PDC, realizada no final de novembro e início de dezembro de 1963, Ney Braga o atacou: "considerando que as dificuldades pelas quais passam o Brasil e o Pa-

${ }^{51}$ DELGADO, Lucilia de Almeida Neves. PTB: do getulismo ao reformismo (1945-1964), op. cit., 1989, p. 245-246.

${ }^{52}$ KUNHAVALIK, José Pedro. Ney Braga: trajetória política e bases do poder. In: OLIVEIRA, Ricardo Costa (Org.). A construção do Paraná moderno: políticos e política no governo do Paraná de 1930 a 1980. Curitiba: SETI, 2004, p. 303.

${ }^{53}$ Idem, p. 309.

${ }^{54}$ Cf. Diário do Paraná, 18 jul. 1963, p. 3. 
raná se devem ao mau governo da União", afirmou: "Eu não sabia que o Jango era tão ruim assim" ${ }^{55}$ Era o indício do rompimento entre Ney Braga e Jango, oficializado em dezembro de 1963. Após romper com Jango, Ney Braga estreitou relações com os governadores conspiradores Carlos Lacerda (UDN), da Guanabara, José de Magalhães Pinto (UDN), de Minas Gerais, Adhemar de Barros (PSP), de São Paulo e Ildo Meneghetti (PSD), do Rio Grande do Sul, entre outros.

Isolado politicamente, Goulart, no final de 1963, optou pela reaproximação com as organizaçôes à esquerda e pela adoção de medidas nacionalistas e de cunho reformista. Ao mesmo tempo, os grupos golpistas civis e militares aceleraram a conspiração em marcha, sobretudo após o "comício das reformas", realizado no dia 13 de março de 1964 na Central do Brasil, no Rio de Janeiro. Durante o emblemático comício, Jango se comprometeu por um programa máximo de reformas de base.

Por outro lado, os setores conservadores civis, eclesiásticos e militares passaram a fazer forte campanha contra Goulart, difundindo que o comício do dia 13 era um indício que o governo havia começado sua escalada para a implantação do regime comunista no país. Assim, sob a bandeira do anticomunismo, da defesa da fé religiosa, da moral e propriedade privada, cerca de 400 a 500 mil pessoas saíram pelas ruas de Sáo Paulo, no dia 19 de março de 1964, na manifestação conhecida como "Marcha da Família com Deus pela Liberdade", na qual protestavam contra o governo de Jango e "pedindo que Deus e os militares salvassem o Brasil do comunismo". ${ }^{56}$ Em suma, as Marchas da Família com Deus pela Liberdade tinham o propósito de criar um clima favorável à intervenção militar, bem como incitar as Forças Armadas ao golpe de Estado. ${ }^{57}$

O golpe civil-militar, que já vinha sendo arquitetado há algum tempo, foi concretizado nos dias 31 de março e $1^{\circ}$ de abril de 1964, encontrando poucas resistências e sagrando-se vitorioso com facilidade. As explicaçôes para seu êxito são as mais variadas e já foram amplamente discutidas pela historiografia brasileira.

Após a consumação do golpe tiveram início as perseguiçóes às principais lideranças nacionalistas e reformistas, oficiais e subalternos das Forças Armadas, líderes sindicais, comunistas, estudantes e demais lideranças progressistas, que eram enquadrados como "subversivos". Porém, convém lembrar que as perseguiçôes não se restringiram somente às questóes políticas, uma vez que muitas foram motivadas por revanchismo e desavenças pessoais.

No dia 9 de abril de 1964, o governo militar decretou o Ato Institucional no 1 (AI-1) que, entre outras coisas, reforçou o Poder Executivo e reduziu o campo de açáa do Congresso, estabeleceu a eleição de um novo presidente da República por votação indireta e suspendeu as imunidades parlamentares. Assim, com o objetivo de "limpar o Congresso" dos parla-

\footnotetext{
${ }^{55}$ Cf. O Estado do Paraná, 1o dez. 1963, p. 4.

${ }^{56}$ TOLEDO, Caio Navarro de. O governo Goulart e o golpe de 64. 3. ed. São Paulo: Brasiliense, 1983, p. 99.

${ }^{57}$ Idem, p. 99-100.
} 
mentares acusados de subversão ou corrupção, teve início à série de cassaçóes de mandatos e suspensôes dos direitos políticos por dez anos.

O AI-1 inicialmente cassou os mandatos de 40 parlamentares e suspendeu por dez anos os direitos políticos de outros 66 cidadãos. Dentre os cassados estavam João Goulart, Leonel Brizola, Francisco Julião, Miguel Arraes, Luís Carlos Prestes, entre outros. Na lista também constavam o ex-governador Moysés Lupion (PSD, acusado de corrupção) e o senador Amaury Silva (vice-presidente do PTB paranaense e o último ministro do Trabalho do governo Jango), que rumou ao exílio no Uruguai.

No dia 14 de abril de 1964 ocorreu mais uma série de cassaçôes de mandatos e direitos políticos. Dentre os paranaenses cassados estavam o deputado federal João Simóes (PSD) e alguns petebistas paranaenses, como o tenente-coronel Humberto Molinaro, os deputados estaduais Waldemar Daros e Walter Pecoits (ambos integravam a ala reformista do partido e eram opositores de Ney Braga $)^{58}$.

Em 7 de junho de 1964 houve mais uma série de cassaçôes, dentre elas as do ex-presidente Juscelino Kubitschek (acusado de ter enriquecido durante sua vida pública) e dos deputados estaduais petebistas Leon Naves Bacelos e Luiz Alberto Dalcanale, além do deputado estadual nacionalista Almir Moreira Passos (UDN). ${ }^{59}$

Portanto, a primeira fase de cassaçôes no Paraná alvejou, sobretudo, os deputados que imprimiam forte oposição ao governador Ney Braga, caracterizando-se, assim, como revanchismo político. Posteriormente, durante os anos da ditadura militar, inúmeros outros parlamentares e cidadãos paranaenses tiveram seus mandatos e direitos políticos cassados.

\section{O PTB após o golpe civil-militar: do esvaziamento à extinção da legenda}

Consumado o golpe civil-militar, o marechal Humberto de Alencar Castelo Branco foi eleito indiretamente como o novo presidente da República no dia 11 de abril de 1964 (sendo empossado no dia 15 de abril e, inicialmente, com mandato até 31 de janeiro de 1966). No entanto, convém salientar que os nove membros da bancada do PTB paranaense na Câmara se abstiveram de votar em Castelo Branco, aderindo à orientação do deputado Doutel de Andrade, líder do partido na Câmara. Inclusive a posição da bancada do PTB do Paraná gerou bastante repercussão e foi uma surpresa, uma vez que - mesmo sendo considerada uma das bancadas trabalhistas mais conservadoras da casa - foi a única a seguir integralmente a orientação partidária. Já entre os senadores do PTB paranaense, Rubens de Mello Braga ${ }^{60}$ não compareceu à sessão, enquanto Nelson Maculan votou em favor de Castelo Branco. ${ }^{61}$

\footnotetext{
${ }^{58}$ Cf. Gazeta do Povo, 15 abr. 1964, p. 1.

${ }^{59}$ Cf. Gazeta do Povo, 9 jun. 1964, p. 1.

${ }^{60}$ Rubens de Mello Braga era suplente de Amaury Silva.

${ }^{61}$ Cf. Diário do Paraná, 14 abr. 1964, p. 3.
} 
No âmbito da política paranaense o golpe civil-militar fortaleceu amplamente Ney Braga e enfraqueceu muito o seu principal oponente, o PTB, que teve um senador, quatro deputados estaduais e vários prefeitos e vereadores do interior cassados. No início de junho de 1964, o PTB do Paraná já havia perdido 25\% dos membros da Executiva Estadual, fato semelhante ao ocorrido na Executiva Nacional, onde o partido havia perdido cerca de um quarto dos membros que acabaram de ser eleitos poucos dias antes do golpe. ${ }^{62}$

Enfraquecido politicamente com o golpe civil-militar, o PTB paranaense, no segundo semestre de 1964, procurou se reestruturar. Assim, uma das primeiras decisóes do partido foi manter-se em oposiçáo a Ney Braga ${ }^{63}$ Ademais, o PTB do Paraná também voltou a se articular visando à sucessão estadual de 1965, com Léo de Almeida Neves se lançando como pré-candidato petebista. Porém, no segundo semestre de 1964 também se configurava a possibilidade de ser articulada uma grande coalizáo oposicionista em torno do nome do ex-governador Bento Munhoz da Rocha Neto, alternativa que dividia as opinióes entre os petebistas. ${ }^{64}$

$\mathrm{Na}$ convenção estadual do partido, realizada em junho de 1965, o PTB optou em aderir à coligação oposicionista em torno de Bento Munhoz da Rocha Neto (PR-PTB-PSP-PRP-PST). Do lado situacionista, foi lançada a candidatura de Paulo Pimentel (PTN-PDC-PL). Já a UDN e o PSD mostraram-se bastante divididos e ambos os partidos não aderiram oficialmente a nenhuma das duas candidaturas.

Nas eleiçóes de 3 de outubro de 1965, Paulo Pimentel sagrou-se o novo governador paranaense, obtendo $51,1 \%$ dos votos contra $45,1 \%$ de Bento Munhoz da Rocha Neto. ${ }^{65}$ Com a vitória de Pimentel, Ney Braga consolidou a sua força política no Paraná e, gozando de grande prestígio em nível nacional, foi convidado pelo marechal Castelo Branco a assumir o Ministério da Agricultura no final de 1965. ${ }^{66}$

Por outro lado, outros dois importantes governadores conspiradores, Magalhães Pinto, em Minas Gerais, e Carlos Lacerda, na Guanabara, não conseguiram eleger os seus sucessores, o que representou uma séria derrota ao regime militar. Em resposta, os militares decretaram, em 27 de outubro de 1965, o Ato Institucional no 2 (AI-2), que, entre outras coisas, estabeleceu a eleição indireta para a presidência da República e extinguiu os partidos políticos existentes no país, dando início ao bipartidarismo. Assim, surgiram, de um lado, a Aliança Renovadora Nacional (Arena), partido de apoio ao regime; de outro, o Movimento Democrático Brasileiro (MDB), partido de oposição consentida e controlada. Após a extinção do PTB, a maior parte dos trabalhistas do Paraná migrou para o MDB.

${ }^{62}$ D’ARAUJO, Maria Celina. Sindicatos, carisma \& poder: o PTB de 1945-1965, op. cit., p. 165.

${ }^{63}$ Cf. Gazeta do Povo, 19 jun. 1964, p. 3.

${ }^{64}$ Cf. Gazeta do Povo, 18 ago. 1964, p. 3.

${ }^{65}$ IPARDES. Resultados eleitorais: Paraná (1945-1982), op. cit., p. 11.

${ }^{66}$ Convém lembrar que Ney Braga desempenhou um papel de destaque nos governos militares, ocupando os cargos de ministro da Agricultura (1965-1966) do governo Castelo Branco, senador (1966-1974), ministro da Educação do governo Geisel (1974-1978) e novamente governador do Paraná (1978-1982) — desta vez eleito de forma indireta. 


\section{Consideraçóes finais}

No PTB do Paraná, entre os anos de 1945 a 1955, verificou-se a predominância da corrente "pragmático-getulista", que, liderada por Abilon de Souza Naves, aglutinava políticos profissionais, empresários e profissionais liberais e representavam a elite partidária durante essa fase. Na segunda metade da década de 1950, apesar da continuidade da forte influência dos "pragmáticos-getulistas", houve a ascensão dentro do PTB do Paraná de outras duas fraçôes: os "pragmáticos-reformistas", que defendiam um programa trabalhista, nacionalista e reformista; e os "plutocratas", um grupo de conservadores e fisiológicos que dispunham de abundantes recursos financeiros a serem investidos nas campanhas políticas. Essas três fraçôes, que eram conciliadas dentro do partido por meio da liderança personalista e pragmática de Souza Naves, foram fundamentais — cada uma à sua maneira - para o grande crescimento eleitoral do partido nas eleiçóes estaduais de 1958.

No que concerne à atuação e à importância do PTB no sistema político-partidário do Paraná entre os anos de 1945 a 1965, conclui-se que o PTB, embora tenha nascido fraco e enfrentado inúmeras dificuldades estruturais e financeiras durante os seus primeiros anos de existência, foi o partido que mais cresceu estruturalmente e eleitoralmente no estado ao longo desse período. Embora o PTB não tenha conquistado o governo paranaense, o partido tornou-se uma importante força política e conquistar o seu apoio foi estrategicamente fundamental para que todos os governadores do Paraná garantissem a maioria na Assembleia Legislativa. Por isso, o PTB foi sistematicamente cortejado por todos os governadores paranaenses, revelando-se um partido extremamente pragmático e, muitas vezes, fisiológico, pois procurou barganhar o seu apoio com todos os governadores paranaenses.

\section{Referências bibliográficas}

CODATO, Adriano; KIELLER, Marcio (Orgs.). Velhos vermelhos: história e memória dos dirigentes comunistas no Paraná. Curitiba: UFPR, 2008.

COSTA, Samuel G. História política da Assembléia Legislativa do Paraná. Curitiba: Assembléia Legislativa, 1994, v. 2.

D’ARAUJO, Maria Celina. Sindicatos, carisma \& poder: o PTB de 1945-1965. Rio de Janeiro: FGV, 1996.

DELGADO, Lucília de Almeida Neves. PTB: do getulismo ao reformismo (1945-1964). São Paulo: Marco Zero, 1989.

. Trabalhismo, nacionalismo e desenvolvimentismo: um projeto para o Brasil (19451964). In: FERREIRA, Jorge (Org.). O populismo e sua história: debate e crítica. Rio de Janeiro: Civilização Brasileira, 2001, p. 167-204. 
. Partidos políticos e frentes parlamentares: projetos, desafios e conflitos na democracia. In: FERREIRA, Jorge; DELGADO, Lucilia de Almeida Neves (Orgs.). O Brasil republicano: o tempo da experiência democrática (1945-1964). Rio de Janeiro: Civilização Brasileira, 2003, v. 3, p. 127-154.

FAUSTO, Boris. História concisa do Brasil. 2. ed. São Paulo: EDUSP, 2006.

GOMES, Angela M. de Castro. A invenção do trabalhismo. 3. ed. Rio de Janeiro: FGV, 2005.

IPARDES. Resultados eleitorais: Paraná (1945-1982). Curitiba: IPARDES, 1989.

KUNHAVALIK, José Pedro. Ney Braga: trajetória política e bases do poder. In: OLIVEIRA, Ricardo Costa (Org.). A construção do Paraná moderno: políticos e política no governo do Paraná de 1930 a 1980. Curitiba: SETI, 2004, p. 231-411.

TOLEDO, Caio Navarro de. O governo Goulart e o golpe de 64. 3. ed. São Paulo: Brasiliense, 1983. 